6. The gender component of the European civilization's choice of modern Ukrainianity

7. . "And again I enter the tank ..." Selected texts 2012 - 2016: Articles, essays, interviews, memoirs.

8. Women of the Third Reich: M. Reuter, I. Hess, A.fon Ribbentrop, T.phon Harbow, Z. Leander, E. Baur

9. Hitler

10. Kobzon in conversation with the shepherd confirmed information about the new marriage of Putin's ex-wife

11. Who is the Alpha male? Psychology for men

12. The cult of Putin's personality has reached a new level of insanity

13. The art of insulting
14. The cult of Putin's personality: the path from the tipton to the dictator

15. The song about Putin (Putin's plan)

16. The song "Uncle Vova, we are with you!"

17. The song "Uncle Vova, we are with you!"

18. Raubal (Raubal) Angela (1908 - 18.9.1931,

Munich) - a cousin of A. Hitler

19. The lyrics of the song "My Putin"

20. Family and household economics

21. Sex in big politics. Self-made woman selfteacher

22. Originally from the KGB. Putin's system

23. Russian Westerners do not seek an answer to the challenge of history

удк 94(477.7)

\title{
Віктор Доценко
}

\section{ВПЛИВ ІСТОРИЧНОЇ ПАМ'ЯТІ НА ПОДОЛАННЯ ПОСТКОЛОНІАЛЬНОГО СИНДРОМУ СУЧАСНИМИ УКРАЇНЦЯМИ}

\begin{abstract}
Анотація. У статті на основі аналізу праць сучасних істориків, політологів і суспільствознавців робиться спроба визначити основні фрундаментальні історичні міфи, які використовували радянські та сучасні російські ідеологи для формування історичної свідомості радянської людини та їх подолання в сучасній Україні. Після розвалу імперії українці отримали специфічну модель радянської імперської пам'яті з забронзовілими історичними міфрами та пантеоном історичних героїв і зрадників. Ситуацію ускладнювала наявність вороже налаштованого сусіда, який не міг змиритися з існуванням самостійної України. Континентальна Російсько-радянська імперія прагне реваншу. При цьому російські ідеологи вміло тиснуть на постколоніальну свідомість українських державників. В Україні вітчизняні науковці, діячі культури і науки жорстко протидіють російському ідеологічному наступу. У 1991 р. українські можновладці та гуманітаристи заговорили про формування нових сакральних місць історичної пам'яті, проходив процес формування власного пантеону українських історичних постатей державного, військового і культурно-релігійного спрямування.

Ключові слова: історична пам'ять, імперіалізм, історичний міфр, історична свідомість.
\end{abstract}

\section{Victor Dotsenko}

\section{THE INFLUENCE OF HISTORICAL MEMORY ON MODERN UKRAINIANS' POSTCOLONIAL SYNDROME OVER COME}

\begin{abstract}
The attempts to determine main fundamental historical myths, which were used by soviet and modern Russian ideologists for soviet person historical conscience formation and their overcome in modern Ukraine are represented in the article on the basis of scientific works, analysis of existent historians, political social analysts. The concept of "nation's friendship» dominated in historiography and public discussions in USSR during the decades. This concept successfully hided soviet type of imperialism and colonialism. It was the inheritance of new Ukrainian state. The struggle for Ukrainian nation's conscience between Ukraine and imperial Russia continued during the whole modern history of Ukrainian state. Russia tries to privatize the historical memory about Slavonic state origin and to use it for new imperial ideological project creation. Ukrainian scientistsand culture figures firmly resist to Russian ideological offensive at the same time getting tiny support from politicians. The winner in the war for national Ukrainian identity saving and Ukrainian political nation creation is going to be a person who will reveal the real Ukrainian history without ideological myths and post-imperial stereotypes.
\end{abstract}

Keywords: historical memory, imperialism, historical myth, historical conscience.

Розпад 1991 р. радянської імперії та поява на політичній карті Європи нової держави Україна супроводжувався складними культурно-політичними та історико-ідеологічними змінами, які мали сформувати нову національно-ідеологічну парадигму. До процесу творення нової історичної пам'яті долучилися вітчизняні та діаспорні історики, культурологи, суспільствознавці і політичні діячі. Їхня діяльність супроводжувалась подоланням історичних міфрів і радянської історичної парадигми, яка за десятки років існування радянської тоталітарної імперії міцно вкоренилась в свідомості українців і стала невід'ємною частиною їх культурно-політичної свідомості. Навіть зараз, після двох революцій і україно-російської війни не відбулося остаточного подолання сучасними українцями постколоніального синдрому з його історично-культурними фобіями та міфрами. Процес ламання старого і творення нового 
продовжується. До висвітлення складних процесів творення нової історичної пам'яті долучилися ряд вчених і культурних діячів. Необхідно виділити дослідження Я. Грицака, Л. Нагорної, В. Гриневича, Л. Кармазіної та інших. Однак залишається малодослідженим питання впливу історичної пам'яті на подолання постколоніального синдрому сучасного українського суспільства. Метою нашої статті $\epsilon$ спроба визначити основні фундаментальні історичні міфи, які використовували радянські ідеологи для формування історичної свідомості радянської людини та їх подолання в сучасній Україні.

Упродовж десятиліть в Радянському Союзі в історіографії і публічному дискурсі панувала концепція «дружби народів», яка вдало приховувала радянський тип імперіалізму та колоніалізму. Як пише Ю. Пивоваров, радянські ідеологи створили настільки «неймовірно гнучку та адаптивну» історичну схему, яка дозволила партійно-радянським функціонерам використовувати їі як «соціальну зброю, за силою своєї руйнівності й переконливості співставну з ядерною» [8, с. 65-66]. Формування концепції розпочалося в кінці 1920-х рр. Радянські ідеологи відмовились від класового підходу до розуміння історії російського та інших народів, які увійшли до нової радянської імперії. На замовлення «вождя всіх народів» історики на початку 1930-х рр. звернулися до російської імперської моделі історичної пам'яті, модернізували її і створили нову історичну модель міжнаціональних стосунків. Як зазначає Ентоні Д. Сміт, для формування національної спільноти з ії ідентичністю необхідно мати власний міф про походження і міф про етнічну обраність, обидві групи міфів увиразнюють вимір спільноти [9, с. 66]. Радянські ідеологи розробили концепцію спільного походження східнослов'янських народів і існування в Києво-Руській державі давньоруської народності. Міф про спільну історичну колиску українців, білорусів і росіян згодом було доопрацьовано. 3'явився міф про етнічну обраність російського народу та його державницьку традицію. Саме російський народ, який зумів вижити під час ординської навали і створити православну державу, мав об'єднати в ній всіх своїх менших братів, захистивши їх від згубного впливу західної латинської цивілізації. Саме богообраний народ та його держава врятували білорусів і українців від знищення [2].

Упродовж існування радянської держави партійно-радянські функціонери активно використовували російський імперський міф про «вороже оточення». Він завжди набирав обертів тоді, коли сама Росія-СРСР загрожувала світові, ставала небезпечним агресором. Війни та експансіоністську політику завжди виправдовувала теза захисту пригнічених народів. Так було у 1939 р. - допомога західним братам українцям і білорусам, у післявоєнні роки - допомога братнім народам Центральної Європи будувати соціалізм, у 2014 р. тезу використали для допомоги російськомовному населенню Криму та Південного-Сходу України.
Частиною радянської історичної схеми став міф про об'єднання українців 3 росіянами під час Переяславської ради 1654 р. Радянські ідеологи доводили тезу про прагнення українського народу і його керівника гетьмана Б. Хмельницького долучитися до Московського царства та знайти там захист від польських католиків. Урочисте святкування 1954 р. Переяславської ради ознаменувало остаточне утвердження в свідомості радянських людей нової імперської історичної схеми.

Упродовж 1960 - 1980-х рр. радянський ідеологгічний проект переріс у концепцію конструювання «нової радянської людини», яка мала втратити національну ідентичність, повернутися до спільної мови, історії та культури. Фундаментом для формування «нової радянської людини» стала російська мова, її імперська історія і спільна соціалістична культура.

Необхідно зазначити, що творці радянських ідеологем виявили неабияку винахідливість у використанні історичної пам'яті. Було сконструйовано «двоповерхову» ідеологічну модель. На першому поверсі знаходилась система маніпулятивного контролю $з$ людською поведінкою, а на другому конструювалася схема ірраціональної, метаполітичної свідомості з елементами утопії і міфів. Міфи були підняті у ранг офріційної ідеології з її сак ральними формулами, ритуалами та пантеоном героїв [7, c. 180]. Поєднання тотального контролю за суспільством, знищення носіїв іншої ментальності та історичної пам'яті, синтезування нової інтелігенції дозволило радянським ідеологами повністю контролювати свідомість пересічних радянських громадян та формувати в їхній уяві нове «фіктивне» історичне минуле.

Отже, після розвалу імперії українці отримали специфічну модель радянської імперської пам'яті 3 забронзовілими історичними міфами та пантеоном історичних героїв і зрадників. У більшості громадян нової держави збереглись викривлені уявлення про власну історію та державницькі традиції українців. Значна частина населення зберегла радянську ідентичність з ії «дружбою народів», спільним для слов'янського світу ворогам і величною російською культурою.

Ситуацію ускладнювала наявність вороже налаштованого сусіда, який не міг змиритися 3 існуванням самостійної України. Континентальна Російсько-радянська імперія прагнула реваншу. При цьому російські ідеологи вміло тиснули на постколоніальну свідомість українських державників.

На початку 1990-х рр. українські державні інституції мали працювати у царині дослідження і конструювання нового минулого України. Вони мали створити спільну модель історичного бачення тяглості етнонаціонального буття, етнонаціональних символів і цінностей, національної свідомості. Влада для подолання російського колоніалізму мала діяти в напрямку конструювання української політики пам'яті, потрібно було виробити практики й норми, пов'язані $з$ 
регулюванням колективної пам'яті. Однак державна політика відновлення та збереження історичної пам'яті не була цілісною, стратегічно вивіреною, вона мала здебільшого ситуативний характер. Національне примирення і консолідація українського суспільства не розглядались як головний напрямок гуманітарного розвитку, а скоріше як додаток до якихось більш резонансних проблем. Світовий досвід переконував, що у процесі відродження історичної пам'яті важливу роль відіграють спеціально створені з цією метою урядові структури та науково-дослідні установи, які покликані неупереджено висвітлювати історичне минуле, що допомагало громадянам не лише розібратись у історії, але й зорієнтуватися у поточних подіях, процесах і явищах.

Держава упродовж двох десятиліть не опікувалась формуванням нової історичної пам'яті українців. Діючі політико-історичні інституції, що опікувалися проблемою історичної пам'яті, мали недостатньо можливостей змінити історичну свідомість українства. Це значно стримувало формування української нації. Політики не реагували на заклики історичної спільноти закінчити битву історичних пам'ятей і приступити до побудови нової української державної історичної політики. За В. Кривошеєю, державна політика пам'яті - це визначення владними центрами символічних подій, національних героїв, місць пам'яті, цілеспрямовані дії для їх популяризації [5, с. 27]. В Україні розвивались новітні візії проблеми конструювання спільної пам'яті. В умовах посткомунізму вони виявились роздвоєними: між потребою зобов'язати пам'ятати відповідним чином та прагненнями утвердити право пам'ятати у свій власний, неповторний спосіб. Полеміка відносної ролі та значення держави, а також інших громадсько-політичних акторів у конструюванні пам'яті знайшли відображення у теоретичних конструкціях.

Показовим $€$ звернення до історії пам'яті про Києво-Руську державу. Так, про роль старокиївської держави у формуванні національної ідентичності і подоланні російсько-радянських міфів говорив академік М. Жулинський. Він наголосив на тому, що одна лише згадка про Київську Русь, про київські гори і Андрія Первозванного, про хрещення України-Руси - і вже нема потреби дискутувати, який колосальний державотворчий потенціал закладаємо в систему ідеологічних координат для зміни суспільних настроїв і світоглядних установок, які духовні резерви можемо ввести в процес народно-культурної мобілізації. । коли залунали перестрахувальні голоси про те, що Україна не має власної національної ідеї, то мимоволі хочеться запитати: хіба наш духовноморальний ідеал не в державі, ймення якої Київська Русь, не в християнстві як духовній системі? Хіба переривався в культурній свідомості українського етносу цей духовний «зв'язок часів», який сягає глибоких дохристиянських закорінень, хіба традиція спільного буття з іншими етносами на історичній території не дає нам підстави говорити про український етнос як про етнічно-генеологічну політичну націю» [3, с. 114].

Росіяни намагалися одразу приватизувати історію першої слов'янської держави. Як зазначав у своїй розвідці В. Гриневич, В. Путін одразу після обрання його президентом Росії поставив директорові інституту історії Росії А. Сахарову питання: «Що будемо робити з Київською Руссю?» [10, с. 336]. Тобто російське керівництво вимагало для обґрунтування сучасного імперського історичного міфу створити новий міф про походження та обраність російського народу і його держави. У 2012 р. відбулися урочистості щодо відзначення 1150-річчя 3 дня заснування російської державності. Російські історики заговорили про те, що Русь зародилась не тільки в Києві, але і в Давньому Новгороді. Тож російська державність не веде свою тяглість виключно від київського періоду. Прийшлі варяги $€$ не скандинавами, а південнобалтськими слов'янами. Витоки слов'янської державності потрібно шукати у донорманський період, а офріційною датою появи держави потрібно вважати 860 р., коли слов'яни взяли Константинополь. Таким чином, російські вчені вважають історією Руської землі «початковим періодом» Російської держави (IX - XII ст.), часом, коли «сформувалися основи російської духовності, мови, культури» в цілому [10, с. 336].

Українські вчені для протидії радянськоросійським історичним міфам про початки державності українців використали напрацювання М. Грушевського. Постала нова схема вітчизняної державницької історії: від слов'янських поселень, Русі-України, Галицько-Волинського князівства, до боротьби за державність у польсько-литовський період, появи козацької держави - Гетьманщини, перебування українських земель у складі Російської та Австрійської імперій, поява української держави у період національної революції 1917 - 1921 рр., існування формально радянської української державності та здобуття Україною незалежності у 1991 році [6, с. 206-207].

У 1991 р. українські можновладці та гуманітаристи заговорили про формування нових сакральних місць історичної пам'яті. У вересні 1991 р. Кабінет міністрів України прийняв рішення про відновлення Успенського собору в Києво-Печерській лаврі. Згодом було відбудовано Михайлівський золотоверхий монастир. Змінилося ставлення і до Софії Київської. Для обґрунтування державницької традиції тяглості влада Л. Кучма та його наступники використали традиції звеличення князівської влади Києво-Руської доби. До заходів, які відбувалися під час інавгурації Президента України було внесено покладання квітів до пам'ятника князю Володимиру, а також церемонія благословення Президента України настоятелями церков i керівниками релігійних конфесій України в Софійському соборі Національного заповідника «Софія Київська». Покладання квітів мало символізувати спадковість влади, а церковна - мала стати свого роду поєднанням в 
особі Президента традиційного для Київської Русі зв'язку світської і духовної влади.

Паралельно проходив процес формування власного пантеону українських історичних постатей державного, військового і культурно-релігійного спрямування. 10 грудня 1991 р. відбулося затвердження грошової одиниці України - гривні, що мало символізувати зв'язок сучасної України з державною традицією Київської Русі. На паперових банкнотах номіналом 1 і 2 гривні з'явились історичні портрети київських князів-державників - Володимира Великого та Ярослава Мудрого. Вони, на думку Г. Касьянова, мали стати основою пантеону національних героїв [4, c. 11].

В історичній пам'яті сформувався величний образ середньовічного Києва - сакрального міста, столиці слов'янського світу, столиці Русі-України. Основу образу складала дуалістична паралель міста з вічними містами-символами - столицями християнства: Київ - Константинополь, Київ Єрусалим. Як відомо, міський простір Києва формувався за образом Константинополя, який, у свою чергу, забудовувався, маючи ідеалом інше священне місто - Єрусалим. Київські будівлі, споруджені за Володимира і Ярослава Мудрого, знаходили прямі аналогії в архітектурі й семантиці міського простору Константинополя. Пам'ять про Київ як про спадкоємця Константинополя дійшов до сучасності завдяки архітектурним спорудам, які символізують собою Русь-Україну. Перш за все, коло богородичних храмів [1, с. 97]. Для сучасних українців $€$ священною пам'ять про будівництво Десятинної церкви, Успенського собору Києво-Печерського монастиря, храму Успіня Богородиці. Особливе місце займає пам'ять про собор Святої Софії. Кафедральний собор Святої Софії відповідав Єрусалимському храму, імператорський палац палацові царя Соломона. Навіть Золоті ворота Києва для українців символізують тяглість християнської традиції та показують велич Києва - спадкоємця Єрусалима і Константинополя. Саме традиції і міфи києво-руської доби, які успадкувала Україна заклали основу сучасного ідеологічного протистояння колишньої колонії та метрополії.

Спір про приналежність історичної пам'яті києво-руського періоду та християнізацію Русі між українськими патріотами і російськими імперіалістами та прихильниками відновлення радянсько-російської імперії не вщухав упродовж чверті століття. Ще у 1990-ті рр. УПЦ Київського патріархату виступила проти узурпації РПЦ та їх українського сателіта УПЦ Московського патріархату традицій відзначення хрещення Києво-Руської держави князем Володимиром. У 1988 р. відзначення 1000-ліття хрещення стало тріумфом російського православ'я. Свято урочисто відзначали на державному рівні у кращих імперських традиціях.

2013 р. ситуація повторилась. Російські церковно-державні діячі використали річницю Хрещення Русі для пропаганди ідей «русского мира» та встановлення зверхності російського православ'я в Україні. Історична пам'ять про прилучення русичів до світової релігії стала засобом пропаганди російського імперського проекту. Так, В. Путін у своїй урочистій промові повернувся до російської імперської та радянської концепції спільності російського, українського та білоруського народів і оприлюднив головну інтеграційну мету - створення спільного Митного Союзу у межах колишніх радянських республік.

Питання Києво-Руської історичної пам'яті та Хрещення знову стало предметом посиленої уваги російських пропагандистів під час анексії Криму. Під час зустрічі 3 російськими істориками президент Російської Федерації проголосив український півострів «колискою російської духовності». Він сформулював новий ідеологічний міф про те, що в Херсонесі, а не в Києві, князь Володимир прийняв християнство і почав хрестити Русь. В. Путін запропонував написати нову історію Криму як осередку російської цивілізації. 4 грудня 2014 р. у посланні до Федерального зібрання він заявив, що Крим для Росії має «величезне цивілізаційне і сакральне значення» [10, с. 338].

Отже, упродовж всієї сучасної історії української держави між Україною та імперською Росією точиться боротьба за свідомість українського народу. Росія намагається приватизувати історичну пам'ять про походження слов'янської державності та використати іï у створенні нового імперського ідеологічного проекту. В Україні вітчизняні науковці, діячі культури і науки жорстко протидіють російському ідеологічному наступу, при цьому отримуючи мізерну підтримку з боку вітчизняних політиків і «державників». У війні за збереження національної ідентичності українців та появи української політичної нації переможе той, хто зуміє подати справжню історію України без ідеологічних міфів і постімперських стереотипів.

1. Буряк Л.І. Пам'ять у культурному просторі міста (київський контекст) / Л.І. Буряк // Державотворчі та цивілізаційні здобутки українського народу. Національна та історична пам'ять: Зб. наук. праць. - 2013. - №8(15). - С. $94-102$.

2. Єкельчик С. Імперія пам'яті. Російськоукраїнські стосунки в радянській історичній уяві / С. Єкельчик. - К.: Критика, 2008. - 303 с.

3. Жулинський М. Нація. Культура. Література: національно-культурні міфи та ідейно-естетичні пошуки української літератури. - К.: Наукова думка, 2010.

4. Касьянов Г.В. «Хто такі українці і чого вони хочуть»: проблема формування нації [Текст] / Г.В. Касьянов // Життєвий простір України: політичний та гуманітарний виміри (1991 - 2010 роки): Збірник наукових статей / [Г.В. Касьянов, Н.П. Барановська, С.С. Падалка та ін.]. - К. : Інститут історії України НАН України, 2012. - С. 6 - 19.

5. Кривошея В. В. Моделі пам'яті і державна політика пам'яті / В. В. Кривошея // Державотворчі та 
цивілізаційні здобутки українського народу. Національна та історична пам'ять: Зб. наук. праць. 2011. - Вип. 1. - С. 26 -37.

6. Культура історичної пам'яті: європейський та український досвід [Текст] / [Ю. Шаповал, Л. Нагорна, О. Бойко та ін.]; за заг. ред. Ю. Шаповала. - К. : ІПІЕНД, 2013. - 600 c.

7. Нагорна Л.П. Історична пам'ять: теорії, дискусії, рефлексії / Л.П. Нагорна. - К.: ІПіЕНД ім. І.Ф. Кураса, 2012. - 328 c.

8. Пивоваров Ю.С. «... И в розвалинах века» / Ю.С. Пивоваров // Полис. - 2011. - №6. - С. 65 - 66.

9. Сміт Ентоні Д. Культурні основи націй. Ієрархія, заповіт і республіка. Наукове видання / Ентоні Д. Сміт. - К.: Темпора, 2009. - 312 с.

10. Трансформація політичних інститутів України: проблеми теорії і практики / Авт. колектив: М. Михальченко (керівник) та ін. - К.: ІПіЕНД ім. І.Ф. Kypaca, 2016. - 440 c.

\section{References}

1. Buryak I., 2013. Pam'yat u kulturnomu prostori mista (kiïvskij kontekst) [The memory in the cultural space of the city (Kyiv context)]. Derzhavotvorchi ta civilizacijni zdobutki ukraïnskogo narodu. nacionalna ta istorichna pam'yat: zb. nauk. prac. - 2013. - №8(15). P. 94 -102. (in Ukrainian).

2. Ekelchik S., 2008 Imperiya pam'yati. rosijskoukraïnski stosunki v radyanskij istorichnij uyavi [Empire of memory. Russian-Ukrainian relations in the Soviet historical imagination]. Kyiv - 2008. - 303 p. (in Ukrainian).

3. Zhulinskij M., Naciya. Kultura. Literatura: nacionalno-kulturni mifi ta idejno-estetichni poshuki ukraïnskoï literaturi [Nation. Culture. Literature: nationalcultural myths and ideological and aesthetic searches for Ukrainian literature]. Kyiv - 2010. (in Ukrainian).

4. Kasyanov G., "Kto taki ukraïnci i chogo voni chochut": problema formuvannya naciï [tekst] ["Who are Ukrainians and what they want": the problem of nation building [Text]]. Kyiv - 2012. - P. 6 - 19. (in Ukrainian).

5. Krivosheya V., Modeli pam'yati i derzhavna politika pam'yati [Memory models and state policy of memory]. Derzhavotvorchi ta civilizacijni zdobutki ukraïnskogo narodu. Nacionalna ta istorichna pam'yat: zb. nauk. prac. - 2011. - vip. 1. - P. 26 -37. (in Ukrainian).

6. Kultura istorichnoï pam'yati: evropejskij ta ukraïnskij dosvid [tekst] [The culture of historical memory: European and Ukrainian experience]. - za zag. red. Yu. Shapovala. Kyiv - 2013. - 600 p. (in Ukrainian).

7. Nagorna I., Istorichna pam'yat: teoriï, diskusiï, refleksiï [Historical memory: theory, discussion, reflection]. Kyiv - 2012. - 328 p. (in Ukrainian).

8. Pivovarov $\mathrm{Yu}$. «... i v rozvalinax veka» [... And in ruins of the century]. 2011. - №6. - P. 65 - 66. (in Ukrainian).

9. Smit E. Kulturni osnovi nacij. ierarxiya, zapovit i respublika. Naukove vidannya [Cultural Foundations of Nations. Hierarchy, testament and republic. Scientific publication]. Kyiv - 2009. $-312 \mathrm{p}$.

10. Transformaciya politichnix institutiv ukraïni: problemi teoriï i praktiki [Transformation of Political Institutions in Ukraine: The Problems of Theory and Practice] avt. kolektiv: m. mixalchenko (kerivnik) ta in. Kyiv - 2016. - 440 p.

\section{удк 902}

\section{Алла Кононенко \\ РОЛЬ СВІТОВОГО КОНГРЕСУ УКРАЇНЦІВ (СКУ) В КОНСОЛІДАЦІЇ УКРАЇНЦІВ В ПОСТКОЛОНІАЛЬНУ ДОБУ}

Анотація. У статті йдеться про те, що для вирішення питань консолідації українців має займатись з молоддю $і$ сама молодь, починаючи з дитячого садка, школи, вищого освітнього закладу разом із своїми вихователяминаставниками. Після відновлення незалежності України досить актуальним стало питання поширення правдивої інформації про Україну та українство у цілому світі, у чому безпосередньо бере участь Світовий Конгрес Українців (СКУ), діяльність якого допомагає донести до української та світової спільноти всю повноту політичного, соціального, економічного та інших аспектів життя української діаспори й Української держави. Вважаю, що найголовнішим у цьому питанні є формування національної ідентичності. Перед собою ставлю за мету з'ясувати яким чином світ може вплинути або допомогти людині, яка не усвідомлює до якої національної групи вона належить. Що вона знає про власну історичну територію, чи володіє і користується мовою держави Україна, яким (чиїм) громадянином себе вважає...

Тож стаття призначається для освітян в першу чергу. Підсумовуючи, слід відзначити, що формування національної ідентичності є одним з головних завдань Української держави на сучасному етапі. Для його реалізації потрібно актуалізувати зусилля освітян усіх рівнів та неурядових організацій у сфері суспільних і насамперед міжетнічних відносин.

Ключові слова: Світове українство, українська діаспора, українська національна ідентичність, етнічні українці, українська мова, суверенітет України, Світовий Конгрес Українців. 